\title{
Business and labour, and human rights in New Zealand*
}

\author{
Amanda Reilly and Jonathan Barrett ${ }^{1}$
}

\begin{abstract}
New Zealand is an economically developed country which has a long human rights pedigree. Nevertheless, the country currently manifests a human rights deficit. In particular, businesses are not generally expected to adopt a human rights perspective which goes beyond mere compliance with the law. Furthermore, existing human rights law is under-enforced. Government has shown little interest in exploring how tools, such as public-sector procurement policies or modern slavery due diligence reporting could be used to encourage businesses to respect human rights. Any activity tends to focus on education and persuasion. In light of this low level of awareness, it is not surprising that few New Zealand organisations have committed themselves to the United Nations Global Compact.
\end{abstract}

The chapter contextualises New Zealand's inaction in this area by locating it within a wider discussion of the status of labour and human rights within the country. We argue that New Zealand's implementation of the fundamental ILO standards is unsatisfactory and constitutional recognition of human rights (including labour rights) is weak. We conclude that if New Zealand is to regain its status as a leader in the area of human rights, government must adopt a more proactive approach to the protection of labour and human rights, including making human rights central to its own operations as well as to committing greater resources to promoting and enforcing human rights among the business community.

\section{Introduction}

New Zealand was in the vanguard of countries which promoted universal human rights, including labour rights. The country was the first to enfranchise women, ${ }^{2}$ and to introduce an eight-hour working day. ${ }^{3}$ It was a founding member of both the International Labour Organization (ILO) ${ }^{4}$ and the United Nations. ${ }^{5}$ Despite this history, a rights deficit is currently evident in New Zealand. The New Zealand Bill of Rights Act 1990 (NZBORA) is neither entrenched nor superior legislation, ${ }^{6}$ the country has not ratified two of the eight fundamental ILO conventions, and government has shown little appetite for combatting modern slavery. In this context, it is unsurprising that very few New Zealand business have committed themselves

* This is a draft chapter. The final version is available in Labour, Business and Human Rights Law, edited by JANICE R. BELLACE and BERYL TER HAAR, 2019, Edward Elgar Publishing Ltd. The material cannot be used for any other purpose without further permission of the publisher, and is for private use only.

1 School of Accounting and Commercial, Victoria University of Wellington. We are grateful to Ashleigh Dale for her research assistance. All cited websites were last accessed on 21 November 2017.

$2 \quad$ See Electoral Act 1893.

3 See 'Eight-Hour-Day Movement' in edited by AH McLintock (ed), An Encyclopaedia of New Zealand (1966) <http://www.TeAra.govt.nz/en/1966/eight-hour-day-movement>.

4 'The ILO in New Zealand' (International Labour Organization) <http://www.ilo.org/asia/WCMS_399591/lang--en/index.htm>.

$5 \quad$ See Colin Aikman, 'New Zealand and the Origins of the Universal Declaration' (1999) 29 VUWLR 1.

$6 \quad$ New Zealand Bill of Rights Act 1990 (NZBORA), s 4. 
to the United Nations Global Compact. ${ }^{7}$ In this chapter, we put into constitutional and legal context, New Zealand's slowness in embracing the United Nations Business and Human Rights 'Protect, Respect and Remedy' agenda ${ }^{8}$ with a particular focus on he first pillar of this agendai.e the State's Duty to Protect Human Rights.. Part One of the Framework for the Guiding Principles ${ }^{9}$ which sets out clear guidelines as to what this duty entails, is used as a framework to evaluate the New Zealand government's action and inaction in this area. We conclude that greater efforts are desirable. Government should take more substantial steps to foster an environment in which business fully respects human rights. At the time of writing, after nine years of a National-led government, a Labour-led administration has been inaugurated (8 November 2017) which is likely to make progress in the areas of need we identify.

\section{New Zealand's human rights obligations}

As an overarching general principle, the Guiding Principles are 'grounded in recognition of: States' existing obligations to respect, protect and fulfil human rights and fundamental freedoms' ${ }^{10}$ It is therefore appropriate to provide some background and evaluation of New Zealand's constitutional arrangements and compliance with its existing human rights obligations.

\subsection{Human rights in the constitution}

New Zealand's constitution, in the words of Sir Geoffrey Palmer and Andrew Butler: ${ }^{11}$

consists of a hodgepodge of rules, some legally binding, others not. It is formed by a jumble of statutes, some New Zealand ones and some very old English ones; a plethora of obscure conventions, letters patent and manuals; and a raft of decisions of the courts.

New Zealand does not have a Bill or Charter of Rights against which other laws can be benchmarked. NZBORA, which is supplemented by the Human Rights Act 1993, ${ }^{12}$ is not

7 As at 21 November 2017, only nine New Zealand organisations had joined the Global Compact. Of these, only two are classified as companies. See 'Our participants' (United Nations Global Compact, 2017) $<$ https://www.unglobalcompact.org/what-isgc/participants/search?utf8=\%E2\%9C\%93\&search\%5Bkeywords\%5D=\&search $\% 5$ Bcountries $\% 5 \mathrm{D} \% 5$ $\mathrm{B} \% 5 \mathrm{D}=152 \&$ search $\% 5 \mathrm{Bper} \_p a g e \% 5 \mathrm{D}=10 \&$ search $\% 5 \mathrm{Bsort}$ field $\% 5 \mathrm{D}=\&$ search $\% 5 \mathrm{Bsort}$ direction $\% 5$ $\mathrm{D}=\mathrm{asc}>$.

PROMOTION AND PROTECTION OF ALL HUMAN RIGHTS, CIVIL, POLITICAL, ECONOMIC, SOCIAL AND CULTURAL RIGHTS, INCLUDING THE RIGHT TO DEVELOPMENT Protect, Respect and Remedy: a Framework for Business and Human Rights: Report of the Special Representative of the Secretary-General on the issue of human rights and transnational corporations and other business enterprises, John Ruggie (2008) <https://business-humanrights.org/sites/default/files/reports-andmaterials/Ruggie-report-7-Apr-2008.pdf >.

9 Guiding Principles on Business and Human Rights: Implementing the United Nations "Protect, Respect and Remedy framework" United Nations Human Rights Office of the High Commissioner (New York and Geneva, 2011) (UN Guiding Principles).

Ibid, 1.

11 Geoffrey Palmer and Andrew Butler, A Constitution for Aotearoa New Zealand (Victoria University Press, Wellington 2016) 9-10.

This Act prohibits traditional forms of discrimination, including in the workplace. It also charges the Human Rights Commission with promoting all human rights in New Zealand. See Human Rights Act 1993 ss 21 and 22, and 5 respectively. 
superior law. ${ }^{13}$ Itis also not entrenched law in that 'it would be legally possible for our Parliament to repeal the Constitution Act 1986 or the New Zealand Bill of Rights Act 1990 in a single sitting day of the House under urgency, without any public input'. ${ }^{14}$ There are no safeguards in place to prevent this such as a requirement for a super majority. In practice, however, NZBORA can plausibly be described as a 'super-statute', ${ }^{15}$ which is generally effective in protecting fundamental rights, ${ }^{16}$ notably freedom of expression. ${ }^{17}$ Nevertheless, in the face of advice that it would breach NZBORA, ${ }^{18}$ legislation has been enacted removing prisoners' rights to vote, ${ }^{19}$ and denying access to the Human Rights Commission to certain complainants. ${ }^{20}$ With the courts in New Zealand having no power to strike down such egregious legislation, ${ }^{21}$ the ultimate judicial sanction, if the constitution is not to be thrown into turmoil, ${ }^{22}$ is a declaration of inconsistency with NZBORA. ${ }^{23}$ On occasion, government Ministers have shown disdain for human rights. For example, in the run up to the 2017 election, then Police Minister, Paula Bennett publicly stated that serious criminals have fewer human rights than other citizens. ${ }^{24}$ In the light of the ultimate inability of NZBORA to guarantee fundamental human rights, Palmer and Butler have proposed enactment of an entrenched, superior Bill of

13 In terms of section 145 of the Local Government Act 2002, local authority bylaws are subject to NZBORA review. See Schubert v Wanganui District Council [2011] NZAR 233 (HC) for an example of an NZBORA non-compliant local authority bylaw being invalidated by the High Court.

Palmer and Butler, above n 11, 14.

'A super-statute is a law or series of laws that (1) seeks to establish a new normative or institutional framework for state policy and (2) over time does "stick" in the public culture such that (3) the superstatute and its institutional or normative principles have a broad effect on the law-including an effect beyond the four corners of the statute.' See William N Eskridge Jr and John Ferejohn, 'Super-Statutes' (2001) 50 Duke LJ 1215, 1216. The Human Rights Act 1993 can also be classified as a super-statute.

For a discussion of the effectiveness of NZBORA, see Petra Butler, '15 Years of the NZ Bill of Rights: Time to Celebrate, Time to Reflect, Time to Work Harder?' (2006) 4 Human Rights Research Journal 1.

See Andrew Geddis, 'Dissent, the Bill of Rights Act and the Supreme Court' (2013) 11(1) NZJPIL 55.

The Attorney-General considered the Bill 'unjustifiably inconsistent' with the electoral rights guaranteed by NZBORA. See Attorney-General, 'Report of the ATTORNEY-GENERAL under the New Zealand Bill of Rights Act 1990 on the Electoral (Disqualification of Convicted Prisoners) Amendment Bill' (New Zealand Parliament, 2010) <https://www.parliament.nz/resource/enNZ/49DBHOH_PAP19503_1/ac3708f32f29166772800eb9f4f694b25324e7ee>.

See Electoral Act 1993, s 80(1)(d), as substituted by Electoral (Disqualification of Sentenced Prisoners) Amendment Act 2010, s 4.

See New Zealand Public Health and Disability Act 2000, s 70A(2)(c), as inserted by New Zealand Public Health and Disability Amendment Act 2013, s 4.

See, for example, Sauvé v Canada (Chief Electoral Officer) [2002] 3 SCR 519 in which the Supreme Court of Canada held that prisoners have the right to vote under section 3 of the Canadian Charter of Rights and Freedoms. The Canadian Charter is particularly relevant to New Zealand because NZBORA can be seen as a declawed version of the Charter.

On the possibility of the courts challenging Parliamentary sovereignty, see Sir Robin Cooke, 'Fundamentals' [1988] NZLJ 158; Max Harris, 'Is New Zealand Ready for a Marbury v Madison Moment?' (2012) 25(2) NZULR 210.

See Attorney-General v Taylor [2017] NZCA 215. At the time of writing, the Supreme Court had granted leave to appeal but had not heard the appeal.

Demelza Leslie, 'Serious criminals "have fewer human rights" - National' (Radio New Zealand, 3 September 2017) <http://www.radionz.co.nz/news/political/338588/serious-criminals-have-fewerhuman-rights-national>. 
Rights ${ }^{25}$ However, while an entrenched, superior Bill of Rights would be an improvement on the existing state of affairs, the Palmer Butler proposal misses the opportunity to to provide strong and abiding, fundamental rights for everyone who works. While freedom of association and freedom from forced labour are affirmed, no other work rights are justiciable. Furthermore, rights claims under the proposed constitution may only be made by citizens against the state. There is no ability make claims against third parties such as employers.. ${ }^{26}$

\subsection{New Zealand and international agreements}

In the orthodox view, ${ }^{27} \mathrm{New}$ Zealand follows a traditional British heritage, dualist system with regard to international agreements whereby international and domestic law are conceived as discrete bodies of law. ${ }^{28}$ Consequently, even fundamental human rights do not become law until municipal legislation incorporates them or they attain recognition as jus cogens. ${ }^{29}$ But drawing a bright line between international and domestic law is a moot exercise. ${ }^{30}$ As Palmer argues: ${ }^{31}$

this position can no longer be supported, if it ever could, and it certainly cannot be supported in New Zealand. It is not correct to say that in New Zealand international law may apply within the State only when its principles have been incorporated into the internal domestic law of the State. Such a position is incompatible with the obligations that New Zealand has undertaken and the principle of good faith which accompanies them.

Furthermore, under the New Zealand common law, Parliament is presumed to intend its legislation to comply with international obligations. ${ }^{32}$ Courts may also look to the texts of

25 See generally Palmer and Butler, above n 11.

26 We provide a comprehensive critique of Constitution Aotearoa's labour rights proposals in Jonathan Barrett and Amanda Reilly, 'Too Modest a Proposal? Work Rights under the Proposed Constitution Aotearoa' (New Zealand Labour Law Society Conference, Christchurch, 24-25 November, 2017.)

See Law Commission, A New Zealand Guide to International Law and its Sources (NZLC R34, 1996) para 43.

Sir Geoffrey Palmer, 'Human Rights and the New Zealand Government's Treaty Obligations' (1999) 29 VUWLR 57, 60.

Article 53 of the Vienna Convention on the Law of Treaties (23 May 1969) 1155 UNTS 331, entered into force 27 January 1980 defines a peremptory norm of general international law (jus cogens) as 'a norm accepted and recognized by the international community of States as a whole as a norm from which no derogation is permitted and which can be modified only by a subsequent norm of general international law having the same character'. Among other actions, slavery and racial discrimination are considered contrary to jus cogens. See X Yang, 'Jus Cogens and State Immunity' (2006) 3 NZYIL 131. Richard Boast, 'Recent Developments in International Law: The International Criminal Court and the Pinochet Decision' (2003) HRR 5.

See Dame Sian Elias, 'The Impact of International Conventions on Domestic Law' (Conference of International Association of Refugee Law Judges, Auckland, 10 March 2000) <http://www.courtsofnz.govt.nz/speechpapers/Speech10-03-2000.pdf>; Alice Osman, 'Demanding Attention: The Roles of Unincorporated International Instruments in Judicial Reasoning' (2014) 12(2) NZJPIL 345.

Palmer, above n 28, 60 (footnotes omitted). Palmer particularly had in mind the good faith obligation (pacta sunt servanda) under Vienna Convention, above n 32, art 26.

For a discussion, see John Burrows, 'The Changing Approach to the Interpretation of Statutes' (2002) 33 VUWLR 981. 
international agreements, such as ILO conventions, for interpretative assistance, even if New Zealand has not ratified those agreements. ${ }^{33}$

\subsection{Labour rights}

New Zealand has ratified the three fundamental human rights instruments: the Universal Declaration of Human Rights ('UDHR'), ${ }^{34}$ the International Covenant on Civil and Political Rights ('ICCPR'), ${ }^{35}$ and the International Covenant on Economic, Social and Cultural Rights ('ICESCR'). ${ }^{36}$ However, New Zealand has entered four reservations with regard to ICCPR, including one relating to article 22 which concerns trade union representation. Similarly, and for the same reasons, with regard to the ICESCR, 'New Zealand reserves the right not [to] apply article 8 [trade union membership rights] to the extent that existing legislative measures, enacted to ensure effective trade union representation and encourage orderly industrial relations, may not be fully compatible with that article. ${ }^{37}$ These reservations are problematic as they represent an unwillingness to accept fully the concept of freedom of association set forth in international law, but successive governments have made no progress towards removing them. ${ }^{38}$ Furthermore, New Zealand has not ratified the 2008 Optional Protocol to ICESCR which establishes an individual complaints mechanism. ${ }^{39}$

These two covenants juridify the broad principles of UDHR but theNZBORA does not refer to ICESCR at all. It also does not fully incorporate the provisions of ICCPR although it does affirm freedom of association, ${ }^{40}$ freedom of peaceful assembly, ${ }^{41}$ and freedom from discrimination, which interact with the more specific, anti-discrimination provisions of the Human Rights Act, ${ }^{42}$ Otherwise, NZBORA is silent on labour rights. Notable in this regard is the absence of an explicit expression of the right to join a trade union which is provided for in

For example: in Norske Skog Tasman Ltd v Clarke CA181/03, [152], the Court of Appeal, referred to ILO C158 to establish 'minimum acceptable standards for protection against unjustified termination of employment' even though New Zealand has not ratified C158. In NZ Amalgamated Engineering, Printing \& Manufacturing Union Inc v Witney Investments Ltd (formerly Epic Packaging Ltd) [2007] NZCA 599, [83], the Court of Appeal considered C098 which New Zealand has not ratified. In Chief Executive, Unitec Institute of Technology v Tertiary Education Union [2011] NZCA 286, [34], when considering freedom of association under section 47 of the Employment Relations Act 1990 and NZBORA, s 17, the court referred to B Gernigan, A Odero and H Guido, Collective bargaining: ILO standards and the principles of the supervisory bodies (International Labour Office, 2000) which takes into account C098. Universal Declaration of Human Rights (adopted 10 December 1948) UNGA Res 217 A(III).

International Covenant on Civil and Political Rights (adopted 16 December 1966, entered into force 23 March 1976) 999 UNTS 171.

International Covenant on Economic, Social and Cultural Rights (adopted 16 December 1966, entered into force 3 January 1976) 993 UNTS 3.

'Constitutional Issues \& Human Rights' Department of Justice $<$ https:/www.justice.govt.nz/justice-sector-policy/constitutional-issues-and-human-rights/humanrights/international-human-rights/international-covenant-on-economic-social-and-cultural-rights/>. (Bridget Williams Books, 2016) 35.

For a discussion of the political background to New Zealand's failure to ratify the optional protocol, see ibd, 52-53.

NZBORA, s 17.

NZBORA, s 16.

See NZBORA, s 19 and Human Rights Act, s 22. 
article 22 of ICCPR. However, this right is provided for in the Employment Relations Act $2000 .^{43}$

There is a dearth of New Zealand case law and commentary on labour rights and human rights the essence of the legal issue. As Paul Rishworth observes of freedom of association: 'whether it includes associating for a chosen purpose. We have not yet had to unravel these difficult issues in New Zealand'. ${ }^{44}$ Locally published commentary has tended to analyse foreign jurisprudence ${ }^{45}$ or to adopt an ethically-oriented approach, ${ }^{46}$ both of which are somewhat abstract from the boisterous political realities of employment relations.

\section{New Zealand and fundamental ILO conventions}

The United Nations instruments discussed above are inextricably connected to the eight fundamental ILO Conventions. New Zealand has ratified six conventions. The two unratified conventions are the Freedom of Association and Protection of the Right to Organise Convention, 1948 (No. 87) and the Minimum Age Convention Minimum Age Convention, 1973 (No 138).

\subsection{Convention No. 87}

The country's principal employment law, the Employment Relations Act, records promoting 'observance in New Zealand of the principles underlying' C. 87 and its related 'Convention 98 on the Right to Organise and Bargain Collectively' as one of its objectives. ${ }^{47}$ Nonetheless, New Zealand currently is not in a position to ratify C. 87 because the government retains the administrative power to deregister unions. ${ }^{48}$ Furthermore, the right to strike is constrained in that general strikes and secondary strikes are prohibited. ${ }^{49}$ Since the ILO supervisory bodies have expressed concerns regarding New Zealand's non-ratification, progress towards ratification might be expected ${ }^{50}$ but this has not occurred.

In addition to this critique of the constrained right to strike, questions have been raised regarding film workers' rights to freedom of association and to unionise following enactment

43 Part 3 of the Employment Relations Act 2000 pertains to freedom of association. Section s7(a) provides: 'employees have the freedom to choose whether or not to form a union or be members of a union for the purpose of advancing their collective employment interests'. In terms of section 11, individuals must not be subject to undue influence with regard to union membership. Furthermore, section 103 gives an employee the right to bring a personal grievance against their employer if they are discriminated against in employment on the grounds of union activities. There is however no protection from discrimination on the grounds of union activity pre-employment in either the Employment Relations Act or the Human Rights Act.

Paul Rishworth, 'Human Rights' (2015) NZ L Rev 259, 284 (footnote omitted).

See Edward Miller and Jeff Sissons, 'A Human Right to Collective Bargaining?' (2015) 39(3) NZJER 3; Virginia Mantouvalou, 'Labour Law and Human Rights' (2016) 41(2) NZJER 3.

See Jonathan Barrett and Leigh Thomson, 'Returning Dignity to Labour: Workplace Safety as a Human Right' (2012) 37(1) NZJER 82; Jonathan Barrett, 'Employee-Citizens of the Human Rights State' (2016) 41(2) NZJER 21. Zealand Government: Reflections of a former Minister of Labour' (2000) 35(3) NZJER 6. 
of the notorious 'Hobbit' law. ${ }^{51}$ Other law changes brought in by the former National-led government have also had the effect of eroding rights to union membership and collective bargaining. ${ }^{52}$ The new Labour-led government is likely to reverse these provisions. ${ }^{53}$

\subsection{Convention No. 138}

New Zealand has not ratified C.138 on the minimum age for entry into employment because of a cultural perception that it is normal, healthy and non-exploitative for teenagers to engage in part time employment. This stance is maintained even though C. 138 does permit part time work for older teenagers, and makes the distinction between work compatible with schooling and work outside term time. Moreover, the assumption that such work is non-exploitative is challenged by research. ${ }^{54}$ Nevertheless, as C. 138 is a fundamental convention, New Zealand is bound to act in good faith to further its goals. Good faith in this regard could also be shown by amending Schedule 1 of the Customs and Excise Act 1996, which list prohibited imports, in order to ban importation of goods produced by child labour. ${ }^{55}$

\subsection{Compliance with other conventions}

\subsubsection{Forced labour}

New Zealand has ratified both the Forced Labour Convention, 1930 (No 29) and the Abolition of Forced Labour Convention, 1957 (No 105). The ILO's Committee of Experts in reviewing New Zealand's compliance with C. 29 has expressed concerns about prisoners in New Zealand, particularly those in privatised prisons. ${ }^{56}$ Although these workers reportedly sign consent forms, the New Zealand Council of Trade Unions has suggested they are neither free from menace of penalty ${ }^{57}$ nor are they subject to conditions of employment approximating those of free workers. ${ }^{58}$ Concerns have also been expressed concerning the voluntariness of individuals performing community service..$^{59}$

51 Broadly, section 6 of the Employment Relations Act, which defines 'employee', prima facie excludes film workers. The ILO has expressed concerns regarding this. ILO Committee of Experts on the Application of Conventions and Recommendations Direct Request: Right to Organise and Collective Bargaining Convention, 1949 (No. 98) - New Zealand (published 104th ILC session 2015).

Employers may opt out of multiple employer collective agreements (MECAs). They no longer have a duty to conclude bargaining, and may make deductions from pay for partial strikes. See ILO Committee of Experts on the Application of Conventions and Recommendations Direct Request: Right to Organise and Collective Bargaining Convention, 1949 (No. 98) - New Zealand (published 104th ILC session 2015).

Workplace Relations Policy (2017) <http://www.labour.org.nz/workplace_relations_policy>.

Danae Anderson, 'Safe Enough? The Working Experiences of New Zealand Children' (M Phil thesis, Auckland University of Technology 2010).

See Amanda Reilly, 'The Right to Work and Rights' in Margaret Bedggood and Kris Gledhill (eds), Law into Action: Implementing Economic, Social and Cultural Rights in Aotearoa New Zealand (Thomson Reuters 2011) 68.

ILO Committee of Experts on the Application of Conventions and Recommendations Direct Request: Forced Labour Convention, 1930 (No. 29) - New Zealand (published 106th ILC session 2017).

Ibid.

Ibid.

Ibid. 
While New Zealand bans importation of goods made by prison labour, ${ }^{60}$ the country has concluded trade agreements with countries in the Asia-Pacific region which allow forced labour. ${ }^{61}$ Also, New Zealand does not prohibit the importation of goods made by slave labour, ${ }^{62}$ and is not one of the twenty nations which have ratified the optional protocol to $\mathrm{C} 029$ adopted by the ILO in 2014, which includes a commitment to supporting due diligence by both the public and the private sector. ${ }^{63}$

\subsubsection{Worst Forms of Child Labour Convention, 1999 (No. 182) (C182)}

Although New Zealand has ratified the Worst Forms of Child Labour Convention, 1999 (No. 182), most New Zealanders would be horrified to learn that their country has been criticised by the ILO's Committee oExperts for allowing children aged between 15-18 to take part in hazardous work resulting in high injury and fatality rates. ${ }^{64}$ The Committee further observed that 'addressing "gross violation of a core convention" was a matter of urgency' ${ }^{65}$

\subsubsection{Equal treatment}

Although New Zealand has ratified both the Equal Remuneration Convention, 1951 (No 100) and the Discrimination (Employment and Occupation) Convention, 1958 (No 111), the ILO and other United Nations bodies have noted the continuing disadvantage of women, Māori, Pasifika and other ethnic minorities in the New Zealand workforce. ${ }^{66}$ Migrants and the disabled have also been identified as groups subject to discrimination.

\section{Compliance with the UN Guiding Principles}

Having reviewed New Zealand's constitutional arrangements and relationship to existing human rights obligations we now move into a consideration of New Zealand's performance in light of some of the more specific recommendations found in the UN Guiding Principles.

\subsection{Expectation of corporate respect for human rights}

New Zealand businesses must comply with the human rights laws embedded in the Human Rights Act and the Employment Relations Act. However, the state's obligations to clearly express an expectation that businesses should respect human rights extends beyond this bare

$60 \quad$ Customs and Excise Act 1996, s 54(1)(a) and sch 1.

61 The Asia Pacific region has by far the largest number of forced labourers -11.7 million or 56 percent of the global total. See ILO, '21 million people are now victims of forced labour, ILO says' (Press release) <http://www.ilo.org/global/about-the-ilo/newsroom/news/WCMS_181961/lang--en/index.htm>.

On 24 August 2016, the Customs and Excise (Prohibition of Imports Made by Slave Labour) Amendment Bill failed to pass its first reading. This Bill sought to amend the Customs and Excise Act 1996 to 'prohibit the importation of goods made in whole or in part by slave labour' (Clause 4, the 'purpose clause').

Protocol of 2014 to the Forced Labour Convention, 1930 (Entry into force: 09 Nov 2016), art 2(e).

ILO Committee of Experts on the Application of Conventions and Recommendations Observation: Worst Forms of Child Labour Convention, 1999 (No. 182) - New Zealand (published 105th ILC session 2016).

Ibid.

See, for example, ILO Committee of Experts on the Application of Conventions and Recommendations Direct Request: Discrimination (Employment and Occupation) Convention, 1958 (No. 111) - New Zealand (published 104th ILC session 2015). 
minimum. ${ }^{67}$ The commentary to Foundational Principle 2 notes that a range of approaches have been adopted regarding this including requirements on 'parent' companies to report on the global operations of the entire enterprise. ${ }^{68}$ Notably, in New Zealand, no policy consideration has been given to modern slavery reporting as is required in the United Kingdom, ${ }^{69}$ California, ${ }^{70}$ and is proposed in Australia. ${ }^{71}$

Brown and Sycamore $v$ New Zealand Basing Limited, ${ }^{72}$ a recent Supreme Court decision, has, however, bolstered an expectation that human rights - at least, freedom from discrimination and the right to be involved in the activities of a union ${ }^{73}$ - will be respected throughout an enterprise's operation. These provisions are associated with the personal grievance procedure and thus indirectly create statutory rights not to be discriminated against in employment. The case in question concerned a claim of age discrimination. The appellants were Cathay Pacific Pilots based in Auckland and their employer was a Hong Kong registered company which is a wholly owned subsidiary of Cathy Pacific. The appellants had signed employment contracts which established that the proper law of the contract would be Hong Kong law under which the mandatory retirement of the appellants at the age of 55 would be permitted although this would constitute age discrimination in New Zealand. The Supreme Court concluded that, following a purposive interpretation of the Employment Relations Act, the territorial reach of the legislation (and the right not be discriminated against) extends beyond conduct which occurs in the context of an employment agreement not governed by New Zealand law.

\subsection{Enforcement of laws}

The UN Guiding Principles state: 'Failure to enforce existing laws that directly or indirectly regulate business respect for human rights is often a significant legal gap in State practice. ${ }^{74}$ In this regard, the New Zealand government is open to criticism. The Human Rights Act and the Employment Relations Act provide the primary legislative framework of the human rights related law that businesses are expected to comply with. Are these law adequately enforced? The short answer is probably not.

\footnotetext{
$67 \quad$ Guiding Principles, above n 10, 3.

$68 \quad$ Ibid, 4

Modern Slavery Act 2015 (UK) Part 6.

California Civil Code $\S 1714.43$.

71 Parliament of the Commonwealth of Australia, Modern slavery and global supply chains: Interim report of the Joint Standing Committee on Foreign Affairs, Defence and Trade's inquiry into establishing a Modern Slavery Act in Australia <https://www.aph.gov.au/Parliamentary_Business/Committees/Joint/Foreign_Affairs_Defence_and_Tr ade/ModernSlavery/Interim_Report>. [2017] NZSC 139.
}

73 See Employment Relations Act, s 104, which mirrors the discrimination grounds set out in section 21(1) of the Human Rights Act, and s 107. 
The bodies charged with enforcing these laws are the Human Rights Commission and the Labour Inspectorate. Both are under-resourced ${ }^{75}$ and take a primarily reactive approach to enforcement, responding to complaints rather than actively initiating investigations. ${ }^{76}$

Powers of the Labour Inspectorate have been augmented because of a growing recognition of widespread exploitation of migrant workers in some sectors. Despite New Zealand having 'reasonably strong victim support services, specialist law enforcement units, effective and measurable [National Action Plans], and laws, policies and programmes that address cycle of vulnerability', ${ }^{77}$ the Walk Free Foundation estimates that 800 people or 0.018 per cent of New Zealand's population remain subject to some form of modern slavery. ${ }^{78}$ Christina Stringer, who has extensively investigated labour exploitation in New Zealand, reports on behaviour which ranges from relatively petty breaches of labour regulations to overt forms of modern slavery. ${ }^{79}$ Sex trafficking, particularly from Asian countries, is a persistent problem but migrant workers are also 'vulnerable to forced labor in New Zealand's agricultural, construction, viticulture, food service, and hospitality sectors, and as domestic workers' ${ }^{80}$ Following revelations of brutal conditions on certain foreign-flagged ships operating within New Zealand's exclusive economic zone, ${ }^{81}$ with effect from 1 May 2016, all foreign charter fishing vessels have been required to operate under New Zealand's flag and must comply with the country's laws, ${ }^{82}$ notably health and safety at work legislation.

Introduced in 2015, section 98D of the Crimes Act 1961 prohibits trafficking in people. Katja Heesterman observes that prosecutors have preferred to pursue offenders under immigration and employment legislation, rather than general criminal law, ${ }^{83}$ although a landmark conviction demonstrated the plausibility of prosecution under the Crimes Act. ${ }^{84}$ Recent developments in the interaction between immigration and employment law are therefore significant. In terms of amendments to immigration procedures, since 1 April 2017, the Labour Inspectorate can issue stand down notices for periods of between six months and two years to employers which have failed to comply with labour laws. (The stand down period is based on the fine levied for breaches of employment law in specialist forums.) During the stand down period, the affected employer may not employ migrants. ${ }^{85}$ In the first six months of the regime, 70 employers were

Eva Corlett, 'Thousands seeking help over employment breaches" (Radio New Zealand, 7 September 2017) <http://www.radionz.co.nz/news/national/338854/thousands-seeking-help-over-employmentbreaches>.

McGregor et al, above n 38, 197.

Walk Free Foundation, Global Slavery Index 2016 Report (2016) 56.

Ibid 29.

Christina Stringer, 'Worker Exploitation in New Zealand: A Troubling Landscape' (2016) <http://hagar.org.nz/files/Worker-Exploitation-in-New-Zealand.pdf>.

US Department of State, Trafficking in Persons Report 2017 (2017) 300.

Report of the Ministerial Inquiry into the use and operation of Foreign Charter Vessels (2012).

See Fisheries Act 1996, s 103.

Katja Heesterman, 'Protection against Slavery in New Zealand' (2015) 46 VUWLR 185, 193.

See $R$ v Ali [2016] NZHC 2223.

See Immigration New Zealand Instructions: Amendment Circular No. 2017/04 (27 March 2017). 
banned from employing migrant workers. Construction companies, restaurants, an orchard, an electrician but also a major trucking company were stood down. ${ }^{86}$

Clearly, a sufficient complement of labour inspectors is crucial if this strategy is to be effective. Currently, New Zealand has one inspector for every 14,000 employees, whereas the ILO recommends a ratio of one inspector for every 10,000 employees for industrialised countries. ${ }^{87}$ However, in what would be a significant step towards combatting exploitation, the incoming Labour-led government has undertaken to increase the number of labour inspectors over three years so that the ratio would reduce to one inspector for every 9,200 employees. ${ }^{88}$

\subsection{Effective guidance to business}

The Paris Principles are 'a set of international standards which frame and guide the work of National Human Rights Institutions (NHRIs)' ${ }^{89}$ In terms of the principles, NHRIs should, when providing guidance on human rights, 'indicate expected outcomes and help share best practices'. ${ }^{90}$ The Human Rights Commission is the NHRI in New Zealand. To fully comply with the principles, the Commission should be genuinely independent and to report directly to Parliament as an officer of Parliament. ${ }^{91}$ It is not and it is currently not adequately funded or resourced with sufficient expertise at Commission and staff level. ${ }^{92}$ Despite its limited resources, the Commission has sought to publicise and encourage the use of the Guiding Principles. ${ }^{93}$ The Commission held its first (and to date only) Business and Human Rights forum in August 2016. ${ }^{94}$ In contrast, since 2014, the Australian Human Rights Commission has annually convened a Dialogue on Business and Human Rights. ${ }^{95}$

'70 businesses banned from hiring migrants over labour law breaches' The New Zealand Herald (Auckland, 4 October 2017) <http://www.nzherald.co.nz/nz/news/article.cfm?c_id=1\&objectid=11929596>. See 'Labour Inspection, Report III (Part 1B)' (International Labour Conference, 95th Session, Geneva, 2006).

Emile Donovan, 'Labour inspector numbers set to double in 3 years' Radio New Zealand 6 November 2017.

'Paris Principles: 20 years guiding the work of National Human Rights Institutions' 〈http://www.ohchr.org/EN/NewsEvents/Pages/ParisPrinciples20yearsguidingtheworkofNHRI.aspx>.

Philip Alston and Ryan Goodman, Human Rights, The Successor to International Human Rights: Law, Politics and Morals Texts and Materials (OUP 2013) 1480.

McGregor et al, above n 38, 209.

Ibid.

Adam Bennett, 'GCSB bill inadequate: HRC' Otago Daily Times (Dunedin, 12 July 2013) 〈https://www.odt.co.nz/news/politics/gcsb-bill-inadequate-hrc>.

For example, before the reflagging law discussed at 4.2, the Commission suggested that New Zealand businesses associated with foreign charter fishing vessels operating in New Zealand waters should adopt the Guiding Principles to avoid reputational damage. See Henry Clayton, 'Business and Human Rights: Businesses Doing More than Domestic Law Requires’ (2011) 6 Human Rights Research Journal 1, 7.

'Business and Human Rights Forum' Human Rights Commission <https://www.hrc.co.nz/news/business-and-human-rights-forum/>.

See, for example, Global Compact Network Australia and Australian Human Rights Commission, '2016 Australian Dialogue on Business and Human Rights: Building stakeholder engagement as a driver of 


\subsection{Encouraging transparency or requiring communication}

There are virtually no requirements for New Zealand businesses to communicate how they address their human rights impacts. In addition to the absence of modern slavery reporting requirements, New Zealand has limited gender equality reporting. Companies listed on the NZX Main Board stock exchange (excluding overseas companies) must include in their annual reports quantitative data on the gender breakdown of the directors and officers at the financial year end, including comparative figures for the prior financial year end. ${ }^{96}$ Otherwise, New Zealand private sector employers are not required to report on gender equality. In contrast, countries such as Australia and the United Kingdom have recently implemented extensive gender equality reporting requirements.$^{97}$ However, the Green Party, which is a support partner of the new Labour-led government, had previously put forward private members bills requiring gender equality reporting. Julie-Anne Genter, a Green Party MP, is the Minister for Women, and as such, may be able to introduce a gender equality reporting bill as a government initiative

\subsection{Influencing state-associated organisations}

According to the Framework, human rights due diligence is: ${ }^{98}$

An ongoing risk management process...in order to identify, prevent, mitigate and account for how [a company] addresses its adverse human rights impacts. It includes four key steps: assessing actual and potential human rights impacts; integrating and acting on the findings; tracking responses; and communicating about how impacts are addressed.

Three types of enterprises are owned or controlled by the New Zealand government: crown entities, state-owned enterprises and mixed ownership companies. None of these organisations are required to conduct human rights due diligence but there are some mechanisms in place to protect against human rights abuses of employees.

\subsubsection{Crown entities}

Crown entities are public bodies which operate at arm's length from government but are still part of the state sector. They are governed by the Crown Entities Act 2004, as well as their own enabling legislation. ${ }^{99}$ Crown entities must be 'good employers', ${ }^{100}$ a requirement which includes operating an appropriate personnel policy. ${ }^{101}$ A feature of a good employer personnel policy is operating an equal employment opportunities programme, ${ }^{102}$ which is defined as 'a programme that is aimed at the identification and elimination of all aspects of policies,

business respect for human rights' (2016) <http://www.unglobalcompact.org.au/new/wpcontent/uploads/2016/12/FINAL-2016-Aus-Dialogue-on-BHR-Summary-Outcomes-Document-1.pdf >. NZX Main Board Listing Rules, r 10.4.5(j). The NZX is a private company.

See, for example, Gender pay gap reporting: overview (2017) <https://www.gov.uk/guidance/genderpay-gap-reporting-overview>.

Consideration of the ultimate efficacy of a system which conceives human rights compliance as a risk management concern lies beyond the scope of this chapter.

Crown entities include the Accident Compensation Corporation; autonomous crown entities, such as, the Museum of New Zealand Te Papa Tongarewa; crown research institutes and Tertiary Education Institutions; and companies, including Radio New Zealand.

Crown Entities Act, s 118.

Crown Entities Act 2004, s 118(1)(a).

Crown Entities Act, s 118(3). 
procedures, and other institutional barriers that cause or perpetuate, or tend to cause or perpetuate, inequality in respect of the employment of any persons or group of persons'. ${ }^{103}$ This programme should recognise the special employment requirements of various groups (Māori, women, ethnic minority groups and persons with disabilities). ${ }^{104}$

Crown entities are also required to make their good employer personnel policy (including the equal employment opportunities programme) available to their employees; ${ }^{105}$ ensure their compliance with that policy (including its equal employment opportunities programme), and to report in their annual reports on the extent of their compliance. ${ }^{106}$ A key limitation of this reporting requirement is that it simply requires employers to have a policy and comply with it. Regulations which only require the existence of employment opportunities policies have variously been referred to as managerialist 'window dressing', 'empty shells', and 'tick the box'. ${ }^{107}$ The mere existence of a policy does not necessarily lead to implementation mechanisms within organisations. A bare requirement of a policy is also likely to fall short of a comprehensive human rights due diligence process.

\subsubsection{State-owned enterprises}

State-owned enterprises (SOEs) are government-owned companies which operate as commercial businesses and are registered under the Companies Act 1993. ${ }^{108}$ They are also subject to the State-Owned Enterprises Act 1986, section 4 of which provides 'the principal objective of every SOE is to operate as a successful business and, to this end, to be as profitable and efficient as comparable businesses that are not owned by the Crown'. SOEs are also required to be good employers, ${ }^{109}$ which essentially requires them to operate a personnel policy and an EEO programme, although the reporting requirement incumbent on crown entities appears to be absent.

An SOE is also required to be an organisation which exhibits a sense of social responsibility 'by having regard to the interests of the community in which it operates and by endeavouring to accommodate or encourage these when able to do so'. ${ }^{110}$ The standard of accommodating the interests of the community when able to do so seems to fall short of requiring human right due diligence

\subsubsection{Mixed ownership model companies}

\footnotetext{
$103 \quad$ Crown Entities Act, s 3.

104 Crown Entities Act, s 118(2).

105 Crown Entities Act, s 118(1)(b).

106 Crown Entities Act, s 118(1)(c).

107 Kim Hoque and Mike Noon, 'Equal Opportunities Policy and Practice in Britain: Evaluating the "Empty Shell” Hypothesis' (2004) 18 Work, Employment and Society 481.

108 SOEs include Airways Corporation of New Zealand Ltd, Kiwirail Holdings Ltd, Landcorp Farming Ltd, Meteorological Service of New Zealand Ltd, New Zealand Post Ltd, New Zealand Railways Corporation, Solid Energy New Zealand Ltd, and Transpower New Zealand Ltd. Exceptionally, the New Zealand Railways Corporation is not registered under the Companies Act.

109 State-Owned Enterprises Act 1986, s 4(1)(b).

110 State-Owned Enterprises Act, s 4(1)(c).
} 
Mixed ownership model companies are enterprises in which the government holds at least 51 per cent of the shares. ${ }^{11}$ These organisations are regulated by Companies Act 1993, which does not include provisions relating to human rights. Air New Zealand, a mixed ownership model company, is one of the two New Zealand companies which are participants in the UN Global Compact.

\subsection{Procurement}

While governments around the world use public procurement to promote social goals, ${ }^{112}$ the New Zealand government generally does not. Furthermore, it does not incorporate human rights concerns in its commercial transactions. New Zealand is not one of the 58 signatories of ILO Convention 94, ${ }^{113}$ which 'offers a set of straightforward standards that encourage socially responsible public contracting by prohibiting the use of labour costs as an element of competition among bidders. The Convention requires that all bidders meet the highest of locally established working conditions. ${ }^{114}$ Indeed, government procurement in New Zealand is informed by neoliberal principles which are widely considered to be inimical to labour rights. ${ }^{115}$

In addition to the State-Owned Enterprises Act 1986, two other pieces of legislation are of particular relevance because of their advancement of the corporatisation and privatisation of government. The State Sector Act 1988 requires employment and management practices in government administration to mirror the private sector, and the Public Finance Act 1989 promotes transparent, accountable and efficient use of public money. According to Ian Gault, the consequences for public procurement of this legislative triad were: government enterprises ceased to be part of Central Government and became expected to behave 'like private companies in making their purchasing decisions', and government departments themselves were required to pursue a more commercial approach to procurement. ${ }^{116}$ Since government procurement accounts for roughly 18 per cent of gross domestic product, it has great economic significance, and could have similar social and ethical significance. ${ }^{117}$

The Government Rules of Sourcing incorporate five principles and 66 rules. ${ }^{118}$ But the key informing goal is 'value for money over the whole-of-life' which 'means using resources

111 Air New Zealand Ltd, Genesis Energy Ltd, Meridian Energy Ltd and Mighty River Power Ltd. See 'Portfolio of Entities: Mixed Ownership Model Companies' The Treasury (2017) <http://www.treasury.govt.nz/statesector/commercial/portfolio/bytype/mixed>.

See, generally, Christopher McCrudden, Buying Social Justice: Equality, Government Procurement, \& Legal Change (OUP 2007). ILO, C094 Labour Clauses (Public Contracts) Convention, 1949 (No. 94).

International Labor Office, International Labor Standards In Procurement: Integrating The Social Dimension Into Procurement Policies and Practices <http://siteresources.worldbank.org/INTPROCUREMENT/Resources/Consultations-ILO.pdf>.

Two particularly informative texts on New Zealand's neoliberal revolution are Jane Kelsey, The New Zealand Experiment: A World Model for Structural Adjustment? (Bridget Williams Books 1997) and Malcolm McKinnon, Treasury: The New Zealand Treasury 1840-2000 (Auckland University Press 2003).

116 Ian Gault, 'Public procurement in New Zealand' [2005] NZLJ 323, 323.

117 For arguments that government could lead by example with its commercial practices, in particular procurement, see Clayton, above $\mathrm{n} 93$.

118 New Zealand Government Procurement, Government Rules of Sourcing (3rd ed, 2015) $<$ http://www.procurement.govt.nz/procurement/pdf-library/agencies/rules-of-sourcing/procurementgovernment-rules-of-sourcing-v3.pdf $>$. 
effectively, economically, and without waste, and taking into account the total costs and benefits of a procurement (total cost of ownership), and its contribution to the results you are trying to achieve.' ${ }^{119}$ Rule 66 requires disclosure of employee transfer costs under certain circumstances, but those circumstances have narrow scope. ${ }^{120}$ Otherwise the sourcing rules are silent on labour rights.

Government procurement is not wholly lacking a values dimension. ${ }^{121}$ The Auditor-General has advised in general terms about procurement and sustainability. ${ }^{122}$ More specifically, the New Zealand Timber and Wood Products Procurement Policy requires government agencies to buy from legally harvested forests, maintain verification records, and prefer sustainably managed sources. ${ }^{123}$ However these guidelines make no reference to labour or human rights standards.

While some scope exists for judicial review of contract-award decisions, ${ }^{124}$ procurement is generally governed by common law contract principles, ${ }^{125}$ consonant with an economic efficiency approach. ${ }^{126}$ However, the new Labour-led government may put ethical procurement on the agenda, having promised in its manifesto to: ${ }^{127}$

Require all state agencies to only contract with organisations that comply with good employer practices, have a history of adhering to employment legislation, and respect the right of their workers to join a union and bargain collectively.

\subsection{International obligations}

Seeking to promote a single procurement market, under the Closer Economic Relations agreement, ${ }^{128}$ Australian and New Zealand agreed to ' $[\mathrm{u}]$ se value for money as the primary

119 New Zealand Government Procurement, Government Rules of Sourcing (3rd ed, 2015) 3 <http://www.procurement.govt.nz/procurement/pdf-library/agencies/rules-of-sourcing/procurementgovernment-rules-of-sourcing-v3.pdf>.

120 Rule 66 relates to the protections for certain vulnerable workers in the event of a transfer in terms of Part VI of the Employment Relations Act.

121 We do not suggest that procurement policy is unethical but the ethical motivations are instrumental inasmuch as, akin to transparency in financial markets, they seek ensure an efficient procurement market, rather than to valorise virtuous behaviour as an end in itself. Where, then, is the concern for, say human rights or more specific labour rights?

Controller and Auditor-General, Good practice guide: Procurement guidance for public entities (2008) [2.85] <https://www.oag.govt.nz/2008/procurement-guide/docs/procurement-guide.pdf>.

New Zealand Timber and Wood Products Procurement Policy $<$ https://www.mpi.govt.nz/dmsdocument/13843-new-zealand-government-policy-on-purchasingtimber-products $+\& \mathrm{~cd}=1 \& \mathrm{hl}=\mathrm{en} \& \mathrm{ct}=\mathrm{clnk} \& \mathrm{gl}=\mathrm{nz}>$.

124 See Andreas Schulz, Enforcing New Zealand's public procurement regulation through judicial review (LLM thesis, Victoria University of Wellington, 2005); Anthea Williams, 'The justiciability of government contracting decisions' [2015] NZLJ 253.

Gault, above n 116, 328.

See, for example, Robert B Seidman, 'Contract Law, the Free Market, and State Intervention: A Jurisprudential Perspective’ (1973) 7(4) J Econ Issues 553.

'Workplace Relations Policy'(2017) Labour 〈http://www.labour.org.nz/workplace_relations_policy>.

Australia New Zealand Closer Economic Relations Trade Agreement 1983. CER is today more usually referred to as the Single Economic Market ('SEM'). Similar arrangements have been concluded with other countries, including Singapore. 
determinant in all procurement decisions'. ${ }^{129}$ 'Value for money' means 'the best available outcome for money spent. Value for money requires a comparative analysis of all relevant costs and benefits of each proposal throughout the whole procurement cycle (whole-of-lifecosting) ${ }^{\prime}{ }^{130}$ In 2015, New Zealand acceded to the Agreement on Government Procurement in the World Trade Organisation (GPA). ${ }^{131}$ 'The fundamental aim of the GPA is to mutually open government procurement markets among its parties' in terms of 'rules requiring that open, fair and transparent conditions of competition be ensured in government procurement'. ${ }^{132}$ 'The New Zealand Government also endorses the APEC Non-Binding Principles of Government Procurement relating to transparency, value for money, open and effective competition, fair dealing, accountability and due process, and non-discrimination.' ${ }^{, 133}$

New Zealand is a signatory of Trans-Pacific Partnership (TPP). ${ }^{134}$ The procurement provisions were a particular concern for critics. ${ }^{135}$ According to the Ministry of Foreign Affairs and Trade, the TPP procurement provision 'establishes rules ensuring open, fair and transparent conditions of competition in government procurement, which are consistent with New Zealand's Government Rules of Sourcing'. ${ }^{136}$ Indeed, a golden thread links open-tender, transparency, value-for-money, and values-neutrality through domestic polices and existing international obligations. But the TPP does not only apply to central government, it also applies to local government. ${ }^{137}$ This is a particular concern because subnational government may implement localised worker-friendly initiatives. ${ }^{138}$ Indeed, Wellington, New Zealand's capital city, has made tentative moves towards requiring its contractors to pay a 'living wage' (roughly 25 percent higher than the statutory minimum wage). ${ }^{139}$ The TPP may imperil such sociallyoriented requirements.

Due to the Trump administration's aversion to multilateral free trade agreements, progress towards ratification of the TPP appears to have stalled. However, in November 2017, the 11 remaining TPP members 'agreed the legal instrument for the Comprehensive and Progressive

\footnotetext{
$129 \quad$ Australia New Zealand Government Procurement Agreement (Revised September 2013) cl 2(d).

130 Australia New Zealand Government Procurement Agreement (Revised September 2013) cl 1(f).

131 Revised Agreement on Government Procurement < https://www.wto.org/english/docs_e/legal_e/rev-gpr94_01_e.htm>.

'The Trans-Pacific Partnership (TPP) is a free trade agreement (FTA) designed to liberalise trade and investment was agreed in February 2017 between 12 Pacific-rim countries: New Zealand, Australia, Brunei Darussalam, Canada, Chile, Japan, Malaysia, Mexico, Peru, Singapore, the United States and Viet Nam.' Trans-Pacific Partnership <https://www.tpp.mfat.govt.nz/>.

See Ted Murphy, 'Government Procurement and Labour Issues' in Jane Kelsey (ed), No Ordinary Deal: Unmasking the Trans-Pacific Partnership Free Trade Agreement (Bridget Williams Books 2010) 189.
}

137 Tony Holman, Richard Northey and Jane Kelsey, 'Implications of TPPA for Local Government' Expert paper \#6 (2016) 〈https://tpplegal.files.wordpress.com/2015/12/tpp-local-govt.pdf>. Rights' (2009) 18(1) New Labor Forum 88. 
Agreement for the Trans-Pacific Partnership (CPTPP)'. ${ }^{140}$ According to the Ministry of Foreign Affairs and Trade, 'CPTPP will incorporate the original TPP Agreement, with the exception of a few technical provisions ... The Ministers also agreed to a 'List of Suspended Provisions' ... contained in the original TPP'. ${ }^{141}$ One of the suspended provisions is 'Article 15.8.5 - Commitments relating to labour rights in conditions for participation'. ${ }^{142}$ Broadly, article 15.8.5 permits a TPP partner to use its procurement rules to promote the labour rights recognised in the TPP agreement. To this extent, the suspension provisions of the CPTPP must be seen as a retrograde step for workers' rights.

\section{Conclusion}

New Zealand may perceive itself as a world leader in the area of human rights but in this chapter we have argued that the country has not demonstrated sufficient commitment to combatting human rights abuses or to creating a cultural expectation that business should respect human rights. Work needs to be done in strengthening New Zealand's weak constitutional recognition of human rights, including those rights that apply to people at work. We propose an entrenched, superior Bill of Rights that explicitly guarantees the labour rights enshrined in the fundamental ILO conventions. New Zealand also needs to consider its relationship with other important human rights instruments. We therefore support Judy McGregor and her co-authors in their strategic proposals for more thoroughly enmeshing New Zealand within international human rights norms, for example, by ratifying the Optional Protocol to ICESCR. ${ }^{143}$ As noted, New Zealand has failed to ratify two fundamental ILO Conventions (C. 87 and C. 138), a regrettable situation which should be rectified.

New Zealand should also ratify the optional protocol to C. 29 which would strengthen its obligations to combat forced labour. If other comparable nations are introducing modern slavery reporting requirement, New Zealand can too. Similarly, gender equality reporting is widely accepted internationally and there is no reason why New Zealand businesses should be exempt from such requirements. Ratification of C. 94 should also be put on the agenda as this would require commitment from the government to insert labour rights clauses into its procurement processes and agreements, which it currently does not do.

With the election of the Labour-led government, there is hope that the government will make more of an effort to make human rights central to its own operations as well as to committing greater resources to promoting and enforcing human rights among the business community. Indeed, if New Zealand is to regain its status as a world leader in the area of human rights, it is critical that this happens.

140 Trans-Pacific Partnership Agreement (TPP) <https://www.mfat.govt.nz/en/trade/free-tradeagreements/free-trade-agreements-concluded-but-not-in-force/trans-pacific-partnership-agreementtpp/>.

141 Trans-Pacific Partnership Agreement (TPP) <https://www.mfat.govt.nz/en/trade/free-tradeagreements/free-trade-agreements-concluded-but-not-in-force/trans-pacific-partnership-agreement$\mathrm{tpp} />$.

142 Annex II - List of Suspended Provisions <https://www.mfat.govt.nz/assets/FTAs-innegotiations/TPP/ANNEX-II_LIst-of-suspended-Provisions.pdf $>$. 